\title{
Feasibility Assessment of Incorporating Copper Slag as a Sand Substitute to Attain Sustainable Production Perspective in Concrete
}

\author{
Akshaykumar M. Bhoi $\mathbb{D}^{1},{ }^{1}$ Yogesh D. Patil, ${ }^{2}$ Hemant S. Patil, ${ }^{2}$ and Madhav P. Kadam ${ }^{1}$ \\ ${ }^{1}$ Civil Engineering Department, NDMVPS's KBT College of Engineering, Nashik, Maharashtra 422013, India \\ ${ }^{2}$ Applied Mechanics Department, Sardar Vallabhbhai National Institute of Technology, Surat, Gujarat 395007, India
}

Correspondence should be addressed to Akshaykumar M. Bhoi; akshaybhoi@gmail.com

Received 28 May 2017; Revised 12 November 2017; Accepted 4 December 2017; Published 11 February 2018

Academic Editor: Jose M. Monzo

Copyright (C) 2018 Akshaykumar M. Bhoi et al. This is an open access article distributed under the Creative Commons Attribution License, which permits unrestricted use, distribution, and reproduction in any medium, provided the original work is properly cited.

\begin{abstract}
Motivated by the sustainable production perspective, a laboratory testing program is exercised to ascertain the feasibility of utilizing copper slag in place of the natural fine aggregate in concrete. Totally, fifteen concrete mixtures were prepared to incorporate copper slag in place of the fine aggregate in concrete. The attributes of concrete specimens made with varying proportions of copper slag were compared (ranging from $0 \%$ to $100 \%$ substitution) at a w/c ratio of 0.44 , and the optimum percentage of copper slag was decided. The $\mathrm{w} / \mathrm{c}$ ratio in the mix containing optimum copper slag percentage was then varied (from 0.42 to 0.36 ) to examine the influence of the change in the quantity of available water on the strength attributes of concrete. Concrete specimens were assessed for workability, density, compressive strength, flexural strength, and split tensile strength. SEM images and X-ray diffractograms of concrete specimens were also studied. The results obtained indicated a significant increase in workability and a small rise in the bulk density of concrete. The study concludes that substituting $60 \%$ sand with copper slag results in better compressive strength compared to control concrete and can be improved further by reducing the w/c ratio in the mix.
\end{abstract}

\section{Introduction}

The remarkable versatility, the ease of construction, and certain durability properties of concrete have made it an essential constituent of construction for decades. The primary challenge before today's construction industry is to meet the demand of efficient and economically viable construction material posed by the huge infrastructural need. The natural ingredients, fine aggregate, and coarse aggregate constitute more than $70 \%$ volume of concrete. The availability of these natural resources is decreasing at a very high pace. In fact, due to the severe problem with natural sand, the construction industry is faced with a pressing need to consider available options to lessen the reliance on natural fine aggregate. On the other front, due to rapid urbanization and industrialization, waste generation has increased tremendously. Traditionally, industries manage their wastes by dumping them into the environment, most of the time without any prior treatment.
Discharging the industrial waste materials into the environment which have significant potential to cause environmental hazards can also become a serious threat to human health. Researchers have conducted many investigations to find practical and environment-friendly ways of disposing off industrial waste in recent years.

Disposal of this enormous volume of industrial waste in concrete appears to be the call of the hour. Sustainable development means wisely using existing resources so that the future demands can be satisfied with ease. Utilization of the industrial waste in concrete can not only provide a cheap and abundant source of the fine aggregate in the concrete but also reduce the environmental pollution resulting in the improved sustainability credentials of the concrete. However, this is possible only if the substitute raw material either improves or at least maintains the attributes of the concrete.

Researchers in the past have successfully produced concrete utilizing industrial waste materials as a substitute 
for natural fine aggregate. Onprom et al. [1], Ghafoori and Bucholc [2], Aggarwal et al. [3], Andrade et al. [4], and Bai et al. [5] experimentally tested the influence of bottom ash as a substitute for natural sand in concrete. Zhu et al. [6] experimentally determined the influence of iron ore tailings as fine aggregate on the concrete. Tripathi and Chaudhary [7] tested the feasibility of utilizing imperial smelting furnace slag in concrete. Al-Bawi et al. [8] have investigated the strength attributes of the concrete comprising recycled glass as a sand substitute.

Copper slag is one of the materials that have a tremendous potential to be adopted in place of the natural fine aggregate in concrete. Around 2.2 ton of copper slag is generated for each ton of copper extracted [9]. Disposal of such vast quantity of waste is a big headache. Motivated by the sustainable production perspective, the present study is intended to explore the viability of incorporating copper slag in place of the natural fine aggregate in concrete. Excellent mechanical and physical attributes of copper slag make it a potential source of fine aggregate. A variety of research work has been performed on the utilization of waste copper slag as the raw material in concrete. Zain et al. [10] used copper slag in the making of cement mortar. The findings of this investigation showed optimum strength performance up to $5 \%$ substitution. Khanzadi and Behnood [11] studied the influence of copper slag together with different silica fume content on the properties of concrete. Results showed better strength with use of copper slag. Al-Jabri et al. [9] conducted an experimental study to examine the impact of copper slag as a sand replacement on the properties of high-performance concrete. The experimental findings indicated a slight increase in density and rapid rise in workability of concrete mixes. Substitution of the 50\% fine aggregate by copper slag showed strength comparable with the strength of conventional concrete. Furthermore, Al-Jabri et al. [12] researched the use of copper slag to produce high-strength concrete. They reported a decline in water demand with the rise in the quantity of copper slag. The study also indicated an enhancement in the properties of concrete comprising copper slag. The experimental work by Wu et al. [13] on the utilization of copper slag in place of fine aggregate in concrete indicated that when less than $40 \%$ copper slag was used, the compressive strength of concrete was observed to be equivalent or superior to the strength of conventional concrete. Wu et al. [14] also studied the attributes of concrete comprising copper slag under dynamic compression. Results indicated improvement in the dynamic compressive strength up to $20 \%$ substitution and a fall in strength beyond $40 \%$ substitution. Brindha and Nagan [15] focused on the utilization of copper slag as a substitute for sand and cement. The result showed that up to $40 \%$ replacement as sand and up to $15 \%$ replacement as cement improves the strength of concrete.

Although a number of experimental studies have been conducted on the attributes of concrete incorporating copper slag as sand substitution, a review of available literature has not produced a single reference on the utilization of copper slag as a sand substitute on the volume basis. This presents an opportunity to examine the influence of substitution of natural fine aggregate with an equivalent volume of copper slag on the concrete properties.
TABle 1: Chemical composition of copper slag using energy dispersive X-ray fluorescence (EDXRF).

\begin{tabular}{lc}
\hline Chemical composition & Copper slag (weight percent) \\
\hline $\mathrm{SiO}_{2}+\mathrm{Al}_{2} \mathrm{O}_{3}+\mathrm{Fe}_{2} \mathrm{O}_{3}$ & 90.09 \\
$\mathrm{SiO}_{2}$ & 33.85 \\
$\mathrm{Al}_{2} \mathrm{O}_{3}$ & 2.79 \\
$\mathrm{Fe}_{2} \mathrm{O}_{3}$ & 53.45 \\
$\mathrm{CaO}$ & 6.06 \\
$\mathrm{MgO}$ & 1.61 \\
$\mathrm{SO}_{3}$ & 1.89 \\
$\mathrm{Na}_{2} \mathrm{O}$ & 0.28 \\
$\mathrm{TiO}_{2}$ & 0 \\
$\mathrm{Mn}_{2} \mathrm{O}_{3}$ & 0.06 \\
$\mathrm{CI}$ & 0.01 \\
Loss on ignition & 0 \\
\hline
\end{tabular}

\section{Experimental Investigation}

The primary aim of this experimental investigation is to substitute the natural sand with industrial waste and copper slag so that the attributes of the concrete should remain least affected. The experiments were carried out using 15 different concrete mixes. The mix CC (control concrete) was made with $100 \%$ natural sand, whereas the Type A mixes were prepared with different proportions (10\% to $100 \%)$ of copper slag (namely, CS10 to CS100) as a substitute for natural sand at a w/c ratio of 0.44. Optimum copper slag content was then found from the Type A mixes and Type B mixes (CW1 to CW4) prepared with $60 \%$ copper slag at a varying water-cement ratio (w/c) (ranging from 0.42 to 0.36 ) with a decrement of 0.02 at each stage. The quantity of copper slag in all mixes was decided on the volume basis so that the total volume of the fine aggregate in all the fourteen mixes was maintained identical to that of natural sand in control concrete. The slump of fresh concrete and 28 days' density of concrete specimens cast were measured. Specimens were tested for compressive, flexural, and split tensile strengths at the age of 7, 28, 56, and 112 days. SEM (scanning electron microscope) images and X-ray diffractograms were also studied.

2.1. Materials and Equipment. Ordinary Portland cement (OPC) of 53 grade conforming to BIS:12269-2013 [16] was utilized for the preparation of all the concrete mixes. Natural river sand brought from Tapi River, India, and copper slag procured from Birla Copper Hindalco Industries (Dahej, Gujarat, India) were used in this experimental study. Natural sand, as well as copper slag, was passed through $4.75 \mathrm{~mm}$ IS sieve. The specific gravity of natural sand and copper slag was experimentally determined to be 2.62 and 3.43, respectively, by using pycnometer as per BIS:2386 part III-1963, R 2002 [17]. Coarse aggregates (basalt) of size $10 \mathrm{~mm}$ and $20 \mathrm{~mm}$ having a specific gravity of 2.77 and 2.82, respectively, were used. The specific gravity of course aggregates was determined by density bucket method as per BIS:2386 part III-1963, R 2002 [17]. Water absorption for natural sand, copper slag, and course aggregate were determined by the conventional method described in BIS:2386 part III-1963, R 2002 [17] and were found to 
TABLE 2: Mix proportion of concrete mixes (quantities per $\mathrm{m}^{3}$ of concrete).

\begin{tabular}{|c|c|c|c|c|c|c|c|c|c|c|}
\hline Sr. no. & Series & $\begin{array}{c}\text { Copper slag } \\
\text { substitution (\%) }\end{array}$ & $\begin{array}{c}\text { Mix } \\
\text { designation }\end{array}$ & $\begin{array}{l}\text { Cement } \\
\left(\mathrm{kg} / \mathrm{m}^{3}\right)\end{array}$ & $\begin{array}{c}\text { Sand } \\
\left(\mathrm{kg} / \mathrm{m}^{3}\right)\end{array}$ & $\begin{array}{c}\text { Copper slag } \\
\left(\mathrm{kg} / \mathrm{m}^{3}\right)\end{array}$ & $\begin{array}{c}20 \mathrm{~mm} \\
\text { aggregate } \\
\left(\mathrm{kg} / \mathrm{m}^{3}\right)\end{array}$ & $\begin{array}{c}10 \mathrm{~mm} \\
\text { aggregate } \\
\left(\mathrm{kg} / \mathrm{m}^{3}\right)\end{array}$ & $\begin{array}{l}\text { Water } \\
\left(\mathrm{kg} / \mathrm{m}^{3}\right)\end{array}$ & $\begin{array}{l}\mathrm{w} / \mathrm{c} \\
\text { ratio }\end{array}$ \\
\hline 1 & $\begin{array}{l}\text { Control } \\
\text { concrete }\end{array}$ & 0 & $\mathrm{CC}$ & 448 & 667.52 & 000.00 & 564.48 & 568.96 & 197.12 & 0.44 \\
\hline 2 & \multirow{10}{*}{ Type A } & 10 & CS10 & 448 & 600.76 & 087.38 & 564.48 & 568.96 & 197.12 & 0.44 \\
\hline 3 & & 20 & CS20 & 448 & 534.01 & 174.77 & 564.48 & 568.96 & 197.12 & 0.44 \\
\hline 4 & & 30 & CS30 & 448 & 467.26 & 262.16 & 564.48 & 568.96 & 197.12 & 0.44 \\
\hline 5 & & 40 & CS40 & 448 & 400.51 & 349.55 & 564.48 & 568.96 & 197.12 & 0.44 \\
\hline 6 & & 50 & CS50 & 448 & 333.76 & 436.94 & 564.48 & 568.96 & 197.12 & 0.44 \\
\hline 7 & & 60 & CS60 & 448 & 267.00 & 524.33 & 564.48 & 568.96 & 197.12 & 0.44 \\
\hline 8 & & 70 & CS70 & 448 & 200.25 & 611.72 & 564.48 & 568.96 & 197.12 & 0.44 \\
\hline 9 & & 80 & CS80 & 448 & 133.50 & 699.11 & 564.48 & 568.96 & 197.12 & 0.44 \\
\hline 10 & & 90 & CS90 & 448 & 066.75 & 786.50 & 564.48 & 568.96 & 197.12 & 0.44 \\
\hline 11 & & 100 & CS100 & 448 & 000.00 & 873.89 & 564.48 & 568.96 & 197.12 & 0.44 \\
\hline 12 & \multirow{4}{*}{ Type B } & 60 & CW1 & 448 & 273.68 & 537.44 & 457.48 & 686.22 & 188.16 & 0.42 \\
\hline 13 & & 60 & CW2 & 448 & 277.34 & 544.64 & 463.60 & 695.40 & 179.20 & 0.40 \\
\hline 14 & & 60 & CW3 & 448 & 281.01 & 551.83 & 469.72 & 704.58 & 170.24 & 0.38 \\
\hline 15 & & 60 & CW4 & 448 & 284.67 & 559.02 & 475.84 & 713.77 & 161.28 & 0.36 \\
\hline
\end{tabular}

be $1.02 \%, 0.02 \%$, and $0.6 \%$ respectively. Throughout the experimental work, drinking water was used for blending the concrete. The chemical composition of copper slag was determined using energy dispersive X-ray fluorescence (EDXRF) spectrometer at the Exova metallurgical services, Mumbai, India, and is shown in Table 1. Scanning electron microscope at the SVNIT (Surat, India) was used to analyse the aggregate-matrix interface of the concrete specimens, and X-ray powder diffractometer at the Savitribai Phule Pune University (Pune, India) was used to identify any crystalline phases formed in the matrix.

2.2. Mix Preparation. The mix proportion of the M40 mix with a target strength of $48.25 \mathrm{MPa}$ was obtained for the concrete mix CC by referring BIS:10262-2009 [18] recommendations. The proportions of cement, fine aggregate, and coarse aggregate were taken as $1: 1.49: 2.53$ at a w/c ratio of 0.44 . The Type A mixes were made by replacing the natural fine aggregate by copper slag in the proportion of $10 \%$ to $100 \%$ volume of natural sand. The Type B mixes were prepared by reducing the water content in the mix CS60 which was an optimum percentage for sand substitution. The mix proportion of candidate mixes is given in Table 2 .

2.3. Preparation of Test Specimens. Cube-shaped specimens with dimensions of $150 \mathrm{~mm}$ for compressive strength test, cylindrical specimens having a diameter of $150 \mathrm{~mm}$ and length of $300 \mathrm{~mm}$ for indirect tensile strength test, and beam specimens with $100 \mathrm{~mm} \times 100 \mathrm{~mm} \times 500 \mathrm{~mm}$ dimensions for the flexural strength test were cast. Totally, 180 cube, 180 cylinder, and 180 beam specimens were cast.

2.4. Test Method. Slump flow test was conducted to investigate workability of the fresh concrete as per BIS:1199-
1959, R 2004 [19]. For the hardened concrete, compressive strength and split tensile strength were measured by testing the cube-shaped and cylinder-shaped concrete specimens, respectively, in uniaxial compression testing machine of $3000 \mathrm{kN}$ capacity as per the guidelines of BIS: 516-1959, R 2004 [20] and BIS:5816-1999, R 2004 [21], respectively. Flexural strength test was performed on beam-shaped specimens on the universal testing machine of $1000 \mathrm{kN}$ capacity for a two-point load as per the test procedure depicted by BIS:516-1959, R 2004 [20].

\section{Test Results and Discussions}

3.1. Chemical and Physical Properties. The chemical constitution of copper slag is given in Table 1. 90.09\% of copper slag is composed of $\mathrm{SiO}_{2}, \mathrm{Al}_{2} \mathrm{O}_{3}$, and $\mathrm{Fe}_{2} \mathrm{O}_{3}$ together. The high concentration of the $\mathrm{Fe}_{2} \mathrm{O}_{3}$ present in the copper slag is the reason for its high specific gravity. The lime content of the copper slag utilized in this study is very low. This indicated that copper slag cannot act as a cementitious material if used in concrete as the quantity of lime available is insufficient to attain the necessary hydration rate.

3.2. Workability and Density of Concrete. The influence of using copper slag in place of natural sand on the workability and the bulk density of candidate concrete specimen are illustrated in Figure 1. For the Type A mixes, a notable rise in the workability of concrete compared to the mix CC can be seen with a rise in the quantity of copper slag in concrete. Also, the Type B mixes show improvement in the workability of the copper slag concrete with a rise in the w/c ratio for obvious reasons. At all substitution percentages, slump of concrete was higher than that of the mix CC. The glossy surface texture and the quality of very low water absorption 


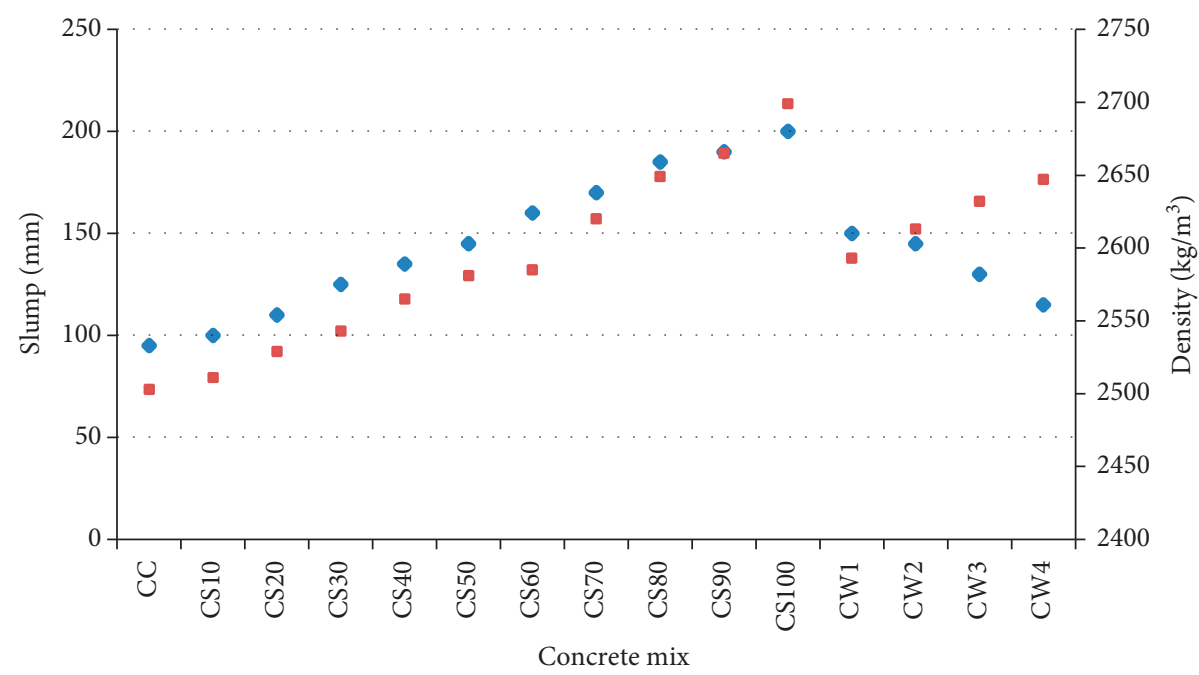

- Slump

- Density of concrete

Figure 1: Slump of fresh concrete and 28 days' density of concrete mix.

of the copper slag are responsible for the substantial increase in the slump. The increased workability due to the presence of copper slag can be used beneficially to manufacture concrete with high workability at low w/c ratio.

The density of the Type A concrete specimen raised with the rise in the copper slag content almost linearly. The Type $B$ mixtures showed a decrease in the bulk density of concrete with the rise in the w/c ratio. The bulk density of the Type A concrete increased owing to the high specific gravity of the copper slag compared to that of natural sand. Due to the difference in the specific gravity, larger quantity of copper slag is required to occupy the same volume as occupied by the natural sand.

3.3. Compressive Strength. The influence of copper slag substitution and varying $\mathrm{w} / \mathrm{c}$ ratio on the compressive strength gained over $7,28,56$, and 112 days of curing age is depicted in Figure 2. The results for the Type A mixes show that, as the quantity of copper slag present in the mix increased, the compressive strength of concrete increased almost linearly up to $60 \%$ substitution of natural sand by copper slag. Beyond $60 \%$ substitution, a notable reduction in the compressive strength was seen. A significant improvement of $4.14 \%, 5.24 \%, 4.62 \%, 6.9 \%, 7.18 \%$, and $10.04 \%$ compared to that of the mix CC in compressive strength at the age of 28 days can be seen in the Type A concrete mixes CS10, CS20, CS30, CS40, CS50, and CS60, respectively. A decrease of $14.41 \%$ in 28 days' compressive strength compared to the mix CC was observed in the compressive strength of the mix CS100 which gained the least compressive strength among all concrete mixes.

From the results obtained for the slump values of concrete and the results of the previous research work [12], it can be inferred that the available water in concrete mix rises with rising quantity of copper slag in the mix. The glossy surface texture and the very low water absorption quality of copper slag particles are the likely causes for this increase. This increased water in the mix which is in excess of the water required for the proper compaction and hydration of the cement paste results in the increased porosity of candidate mixes due to the separation of the concrete ingredients. This results in the reduced performance of the concrete mixes with more than $60 \%$ content of copper slag.

Motivated by these results, the Type B mixes were cast by changing the $\mathrm{w} / \mathrm{c}$ ratio in the concrete mix CS60 which yielded highest compressive strength among the Type A mixes to $0.42,0.40,0.38$, and 0.36 . From Figure 2 , it is clearly evident that the mix CW2 yielded the highest compressive strength among the Type B mixes. However, all Type B mixes showed improved compressive strength compared to the compressive strength of the mixes CC and CS60 at all w/c ratios. The mixes CW1, CW2, CW3, and CW4 showed an increase in compressive strength of $16.69 \%, 26.79 \%, 22.03 \%$, and $13.56 \%$, respectively, compared to the mix $\mathrm{CC}$ at 28 days of curing. Also, the Type B mixes CW1, CW2, CW3, and CW4 achieved an increase in compressive strength of $6.04 \%, 15.22 \%, 10.90 \%$, and $3.20 \%$ over that of the mix CS60 at the curing age of 28 days. As the Type B mixes achieved greater strength compared to the mix CC and Type A mixes, variation of the compressive strength of the Type B mixes compared to the mixes CC and CS60 at 28 days of curing is presented in Figure 3. The reduction in the water content of the Type B mixes might have reduced free water available in the concrete mix which results in less porosity and improved compressive strength.

Because of the abrasion properties associated with its rough surface texture, natural sand can enhance the cohesion between coarse aggregates and cement paste. Despite this, the abrasion property of sand weakens over time because of years of weathering [22]. On the contrary, the improved cohesion due to sharp, angular edges and the better compressibility of the copper slag particles $[13,14]$ compensates the adverse effect of sand to some extent and results in improved compressive strength. 


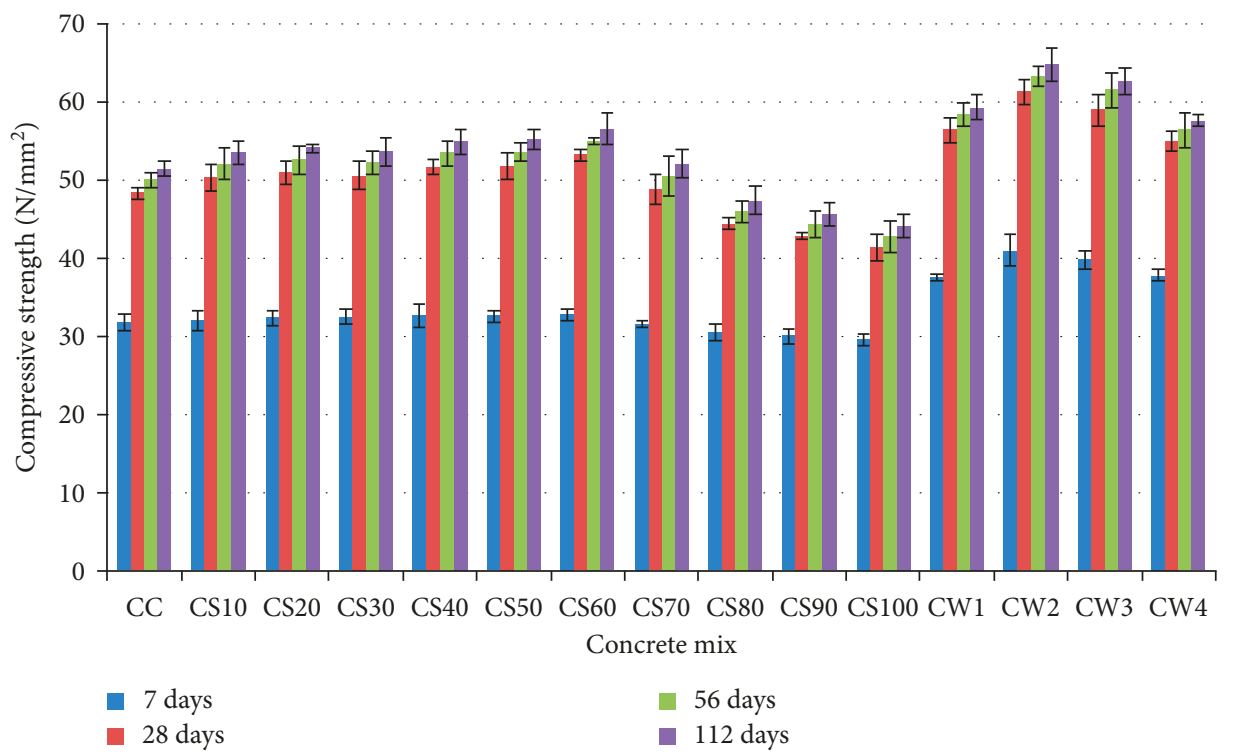

Figure 2: Compressive strength of concrete mixes at different curing ages.

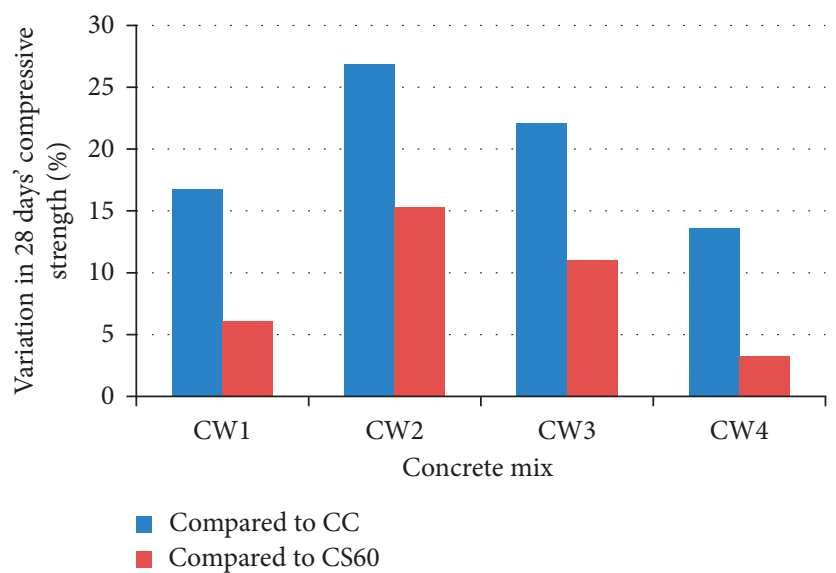

FIgURE 3: Variation in the compressive strength of the Type B mixes.

3.4. Split Tensile Strength. The influence of copper slag substitution on tensile strength of concrete is illustrated in Figure 4. For the Type A mixes, the split tensile strength of concrete improved with the rise in the quantity of copper slag present in the mix till $60 \%$ substitution of natural sand by copper slag. At $70 \%$ substitution, the copper slag concrete gained split tensile strength similar to that of control concrete. On further increase in substitution, a considerable reduction in the split tensile strength was observed. A substantial improvement of $4.24 \%, 4.98 \%, 5.43 \%, 6.87 \%$, $9.16 \%$, and $11.83 \%$ in split tensile strength compared to that of the mix CC can be seen in the concrete mixes CS10, CS20, CS30, CS40, CS50, and CS60, respectively, at the curing age of 28 days. The Mix CS100 gained least split tensile strength among all the concrete mixes which were $12.74 \%$ less than that of the mix CC at the curing age of 28 days.

It is apparent from Figure 4 that the split tensile strength of all Type B concrete mixes is more than that of the mix CC.
An improvement of $8.10 \%, 20.65 \%, 13.54 \%$, and $9.56 \%$ can be seen in the split tensile strength of the mixes CW1, CW2, CW3, and CW4, respectively, compared to the mix CC. The mixes CW2 and CW3 also showed an improvement in the split tensile strength of $7.88 \%$ and $1.52 \%$ over that of the mix CS60. However, the split tensile strength of the mixes CW1 and CW4 was $3.34 \%$ and $2.02 \%$ less than that of the mix CS60. A comparison of the split tensile strength of the Type $\mathrm{B}$ mixes with the mixes CC and CS60 at 28 days of curing is presented in Figure 5. The declined split tensile strength of the specimens with more than $60 \%$ substitution can also be because of increased porosity of concrete due to excess free water remaining in the mix [13].

The relation of the split tensile strength and compressive strength of the Type A and Type B concrete mixes is shown in Figure 6. For all the concrete mixes, the split tensile strength was greater than the value given by formula $0.45 \sqrt{f_{\mathrm{ck}}}$. 


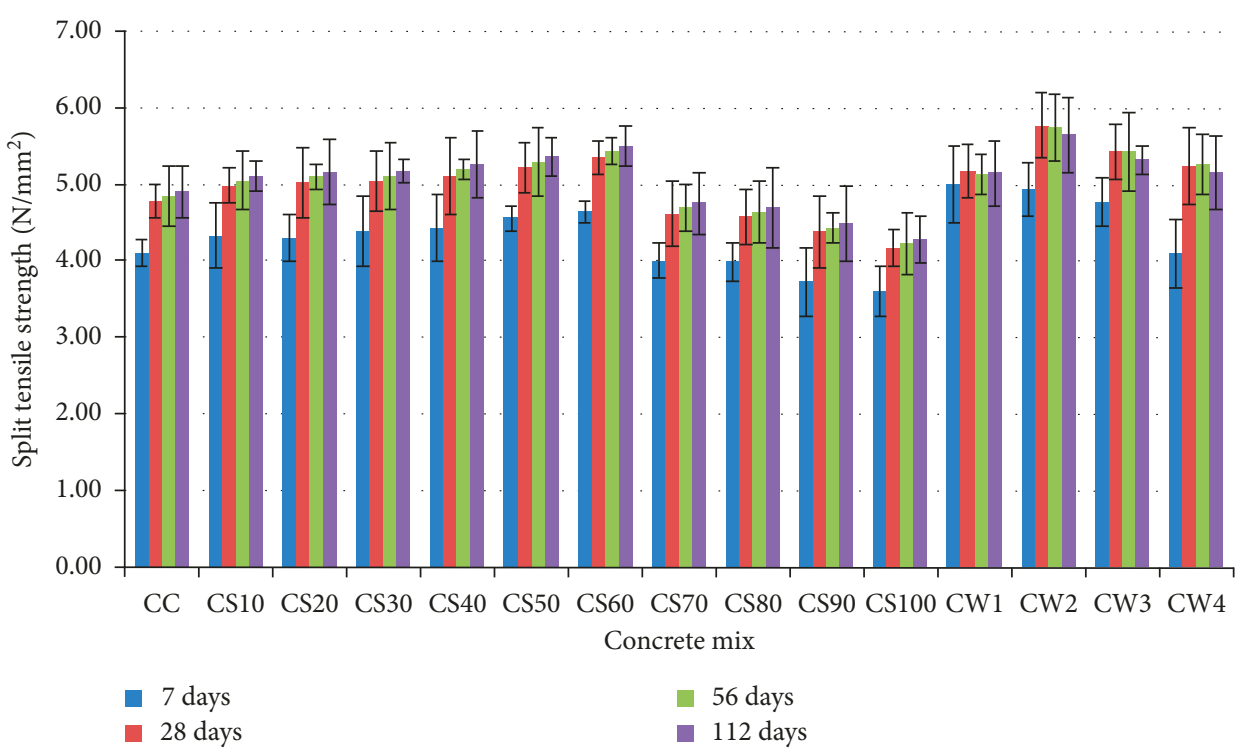

FIGURE 4: Split tensile strength of concrete mixes at different curing ages.

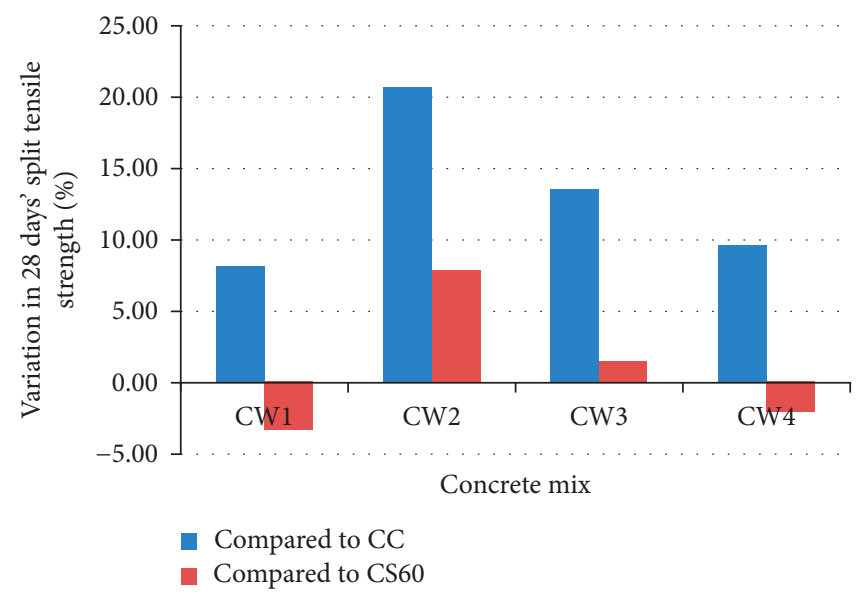

Figure 5: Variation in the split tensile strength of the Type B mixes.

3.5. Flexural Strength. The variation in the flexural strength of candidate mixes with different copper slag substitution is depicted in Figure 7. Similar to the split tensile strength, the flexural strength also increased up to $60 \%$ substitution of natural sand by copper slag. A drop in flexural strength is noted as the percentage substitution increased over $60 \%$. A negligible improvement in the flexural strength of the mix CS10 is observed over the flexural strength of the mix CC after curing time of 28 days. At the curing age of 28 days, the concrete mixes CS30, CS40, CS50, and CS60 achieved flexural strength which was $0.56 \%, 1.17 \%, 2.13 \%$, and $4.28 \%$ greater than that of the mix CC. The mixes CS20, CS70, CS80, CS90, and CS100 showed an decrease of 1.05\%, 1.84\%, $7.55 \%, 10.63 \%$, and $12.76 \%$, respectively, compared to the flexural strength of the mix CC at 28 days' curing age.

Percentage variation in the flexural strength of the Type $\mathrm{B}$ mixes compared to that of the mix CC, and the mix CS60 is illustrated in Figure 8. It is visible from Figure 8 that the mixes CW1, CW2, CW3, and CW4 gained 2.12\%, 9.37\%,
$7.86 \%$, and $3.32 \%$ higher strength respectively compared to the mix CC at 28 days of curing. The mixes CW1 and CW4 showed a decrease of $2.07 \%$ and $0.91 \%$, respectively, in flexural strength compared to the flexural strength of the mix CS60. The 28 days' flexural strength of the mixes CW2 and CW3 improved by $4.88 \%$ and $3.43 \%$ over that of the mix CS60.

The relationship of flexural strength and compressive strength of the Type A and Type B mixes is depicted in Figure 9. The flexural strength of all the concrete mixes was recorded to be greater than $0.7 \sqrt{f_{\mathrm{ck}}}$ [23].

3.6. SEM. Scanning electron microscope (SEM) images of concrete specimens CC, CS60, CS100, and CW2 at 28 days are shown in Figure 10. Small micropores can be seen in Figure 10(a) which shows the microstructure of the mix CC. Figure 10(b) shows microstructure of the mix CS60. The better compressibility of copper slag and reduced pores due to increase in cohesion by the presence of copper slag are the 


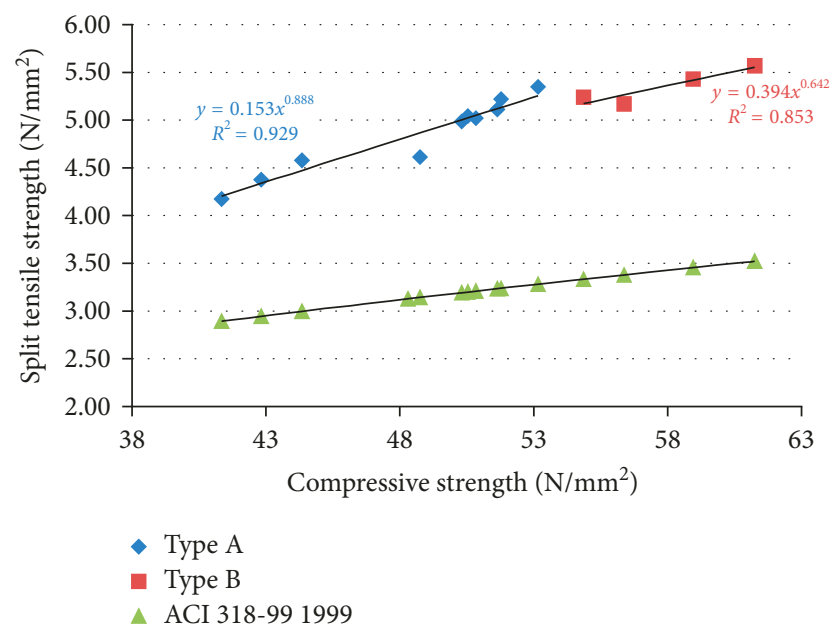

FIGURE 6: Relationship between split tensile strength and compressive strength of concrete mixes at 28 days.

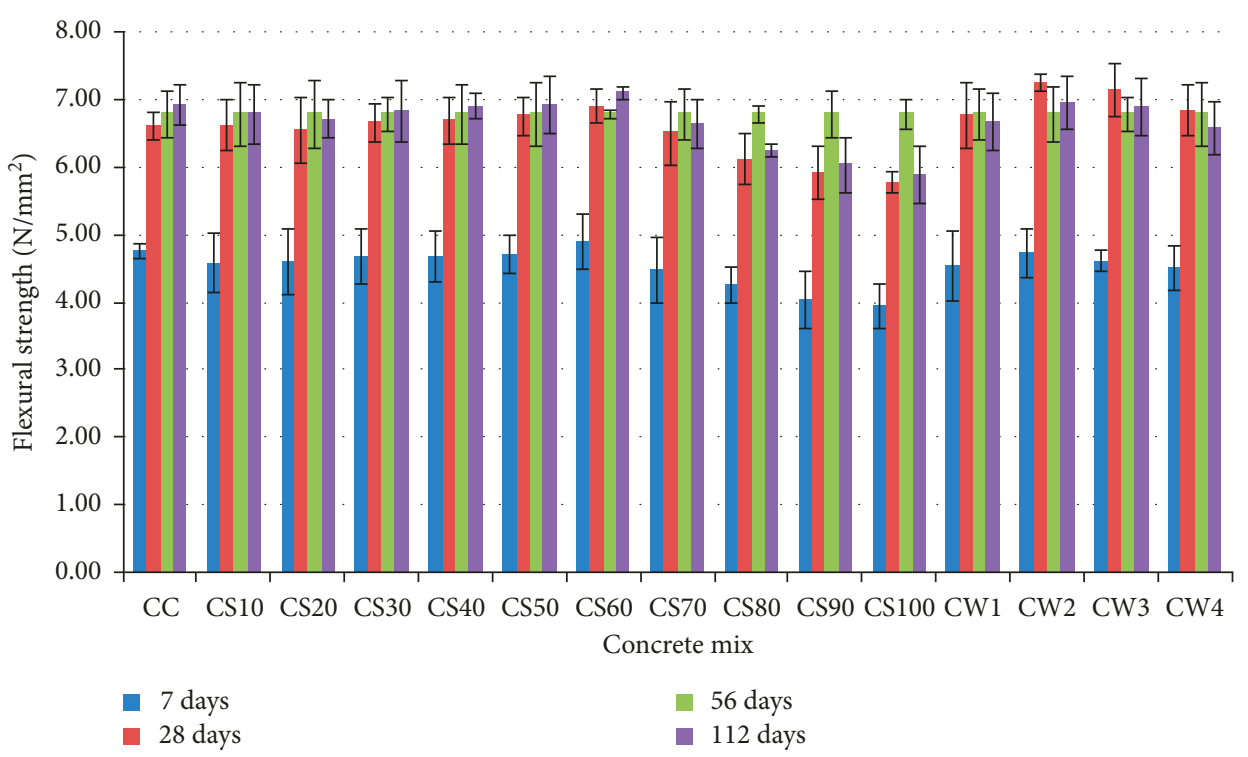

Figure 7: Flexural strength of concrete mixes at different curing ages.

probable reasons for the improvement of the strength. It is evident from Figure 10(c) that micropores are formed in the mix CS100. The interconnectivity of these micropores could have resulted in the reduced flexural strength of the mix CS100. These micropores become the weakest link. The micropores present in concrete quicken the progression of microcracks in concrete and form interconnected fractures which cause the failure of concrete. The decrease in the strength is predominant beyond $60 \%$ substitution because of the rise in the available free water in the mix. Also, more amount of copper slag is required to occupy the volume occupied by natural sand which results in increased surface area of copper slag compared to the surface area of concrete. The increased surface area demands high cement paste in case of high copper slag substitution. The poor binding of copper slag ends in a lowering the strength of concrete. The reduced water content in the mix CW 2 could have reduced the free water available in the mix due to the presence of copper slag. This could be the probable cause for an enhancement in the strength of the mix CW2. The dense microstructure of the mix CW2 is visible in Figure 10(d).

3.7. X-Ray Diffractograms. X-ray diffraction method was used to recognise different phases existing in hardened concrete at the curing age of 28 days. The XRD investigation was performed for diffraction angle 2 theta between $5^{\circ}$ and $80^{\circ}$ on the cement paste isolated from the test specimen and screened through 90-micron sieve. The presence of phases such as alite, gehlenite, calcium silicate, calcium aluminum silicate hydrate, ettringite, silica, calcium hydroxide (portlandite), and calcium 


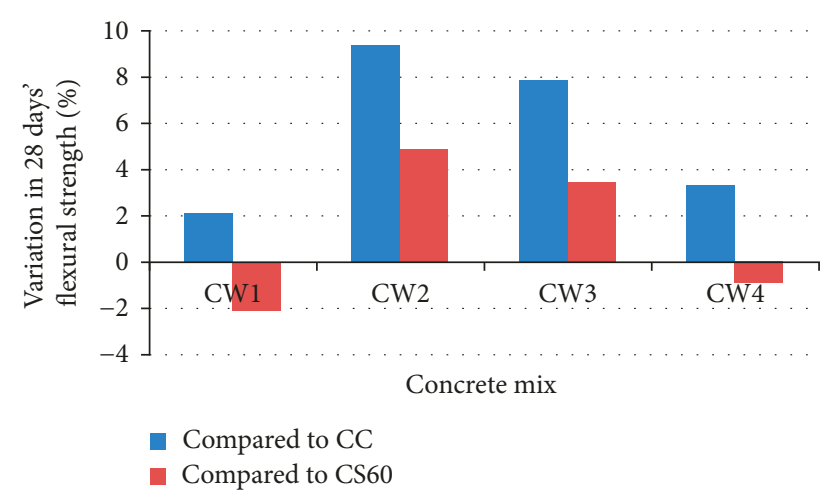

Figure 8: Variation in the flexural strength of the Type B mixes.

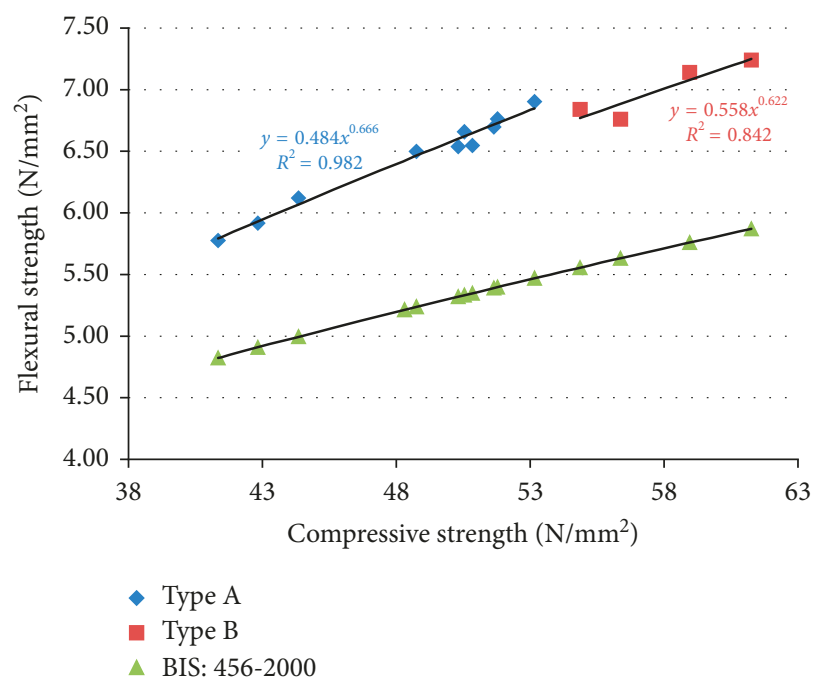

FIgURE 9: Relationship between flexural strength and compressive strength of concrete mixes at 28 days.

carbide can be seen in the concrete. XRD diffractogram of the mix CC (Figure 11) shows the presence of $19 \%$ alite, $14.4 \%$ ettringite, $16.4 \%$ gehlenite, $5.6 \%$ calcium carbonate, $10.1 \%$ portlandite, $18.6 \%$ calcium silicate, and $15.9 \%$ silica. Diffractogram of the mix CS60 (Figure 12) shows the presence of $19.8 \%$ alite, $14.3 \%$ ettringite, $11.5 \%$ gehlenite, $13.7 \%$ calcium carbonate, $9.1 \%$ portlandite, $14.4 \%$ calcium silicate, and $17.1 \%$ silica. Figure 13 shows diffractogram of the mix CS100 and presence of $18.9 \%$ alite, $12.9 \%$ ettringite, $16.4 \%$ gehlenite, $16.9 \%$ calcium carbonate, $3.7 \%$ portlandite, $20.6 \%$ calcium silicate, and $10.6 \%$ silica. Diffractogram of the mix CW2 (Figure 14) shows the presence of $20.4 \%$ alite, $14.7 \%$ ettringite, $17.9 \%$ gehlenite, $6.1 \%$ calcium carbonate, $10.9 \%$ portlandite, $16.6 \%$ calcium silicate, and $13.4 \%$ silica. The diffraction peaks of minerals present in aggregate and weak peaks of poorly crystalline calcium silicate hydrate phase make it difficult to identify the hydrated phases of concrete. The weak diffracted peaks of calcium silicate hydrate are often enveloped by the diffraction peaks of portlandite. There is also a possibility of silicon dioxide peaks interfering with peaks of hydrated phases of concrete. Silicon oxide peaks possibly interfered

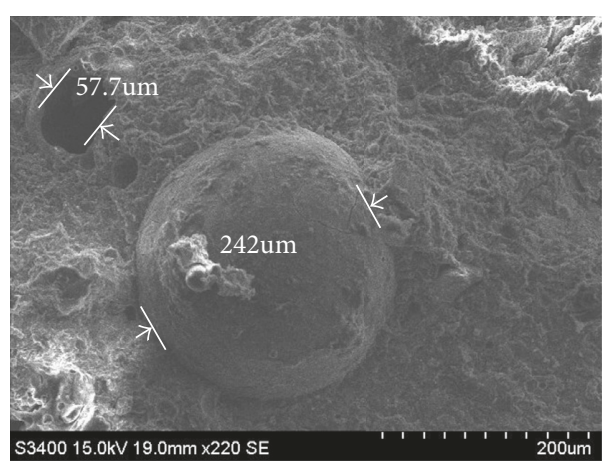

(a)

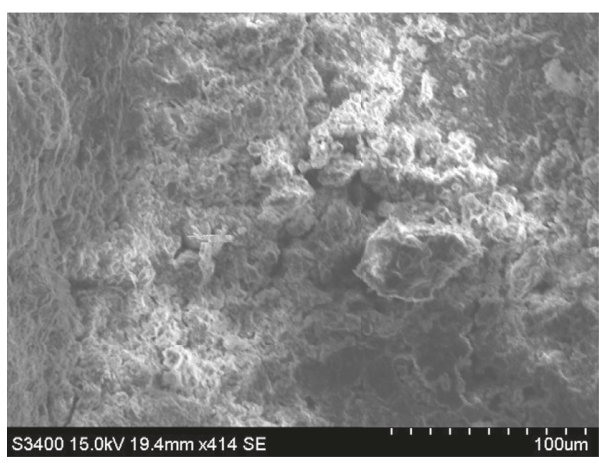

(b)

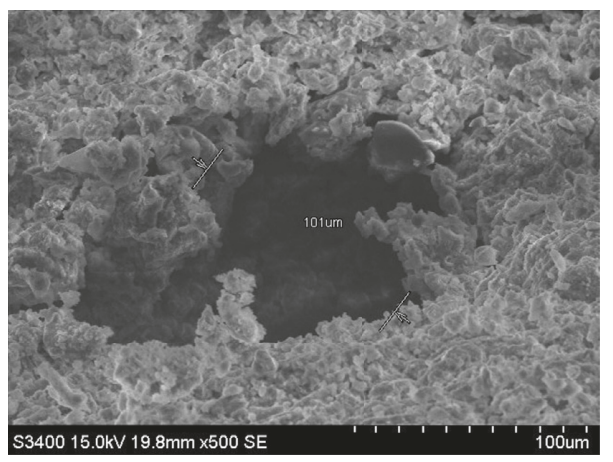

(c)

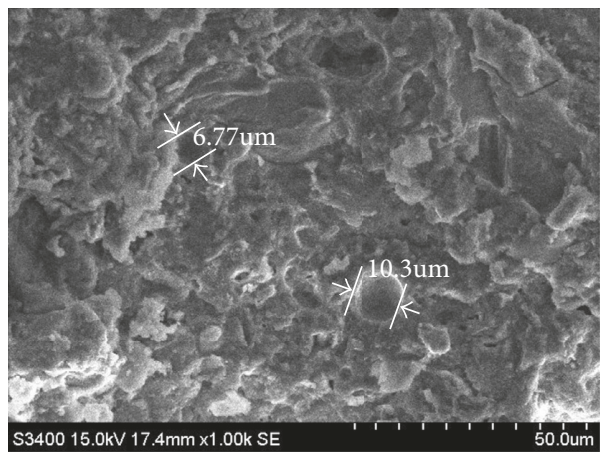

(d)

FIgURE 10: The 28-day SEM images of (a) mix CC, (b) mix CS60, (c) mix CS100, and (d) mix CW2.

with the diffraction peaks of $\mathrm{CSH}$, tricalcium silicate, and dicalcium silicate. $\mathrm{CaCO}_{3}$ significantly impedes the crystallization of portlandite. The amount of $\mathrm{CaCO}_{3}$ 


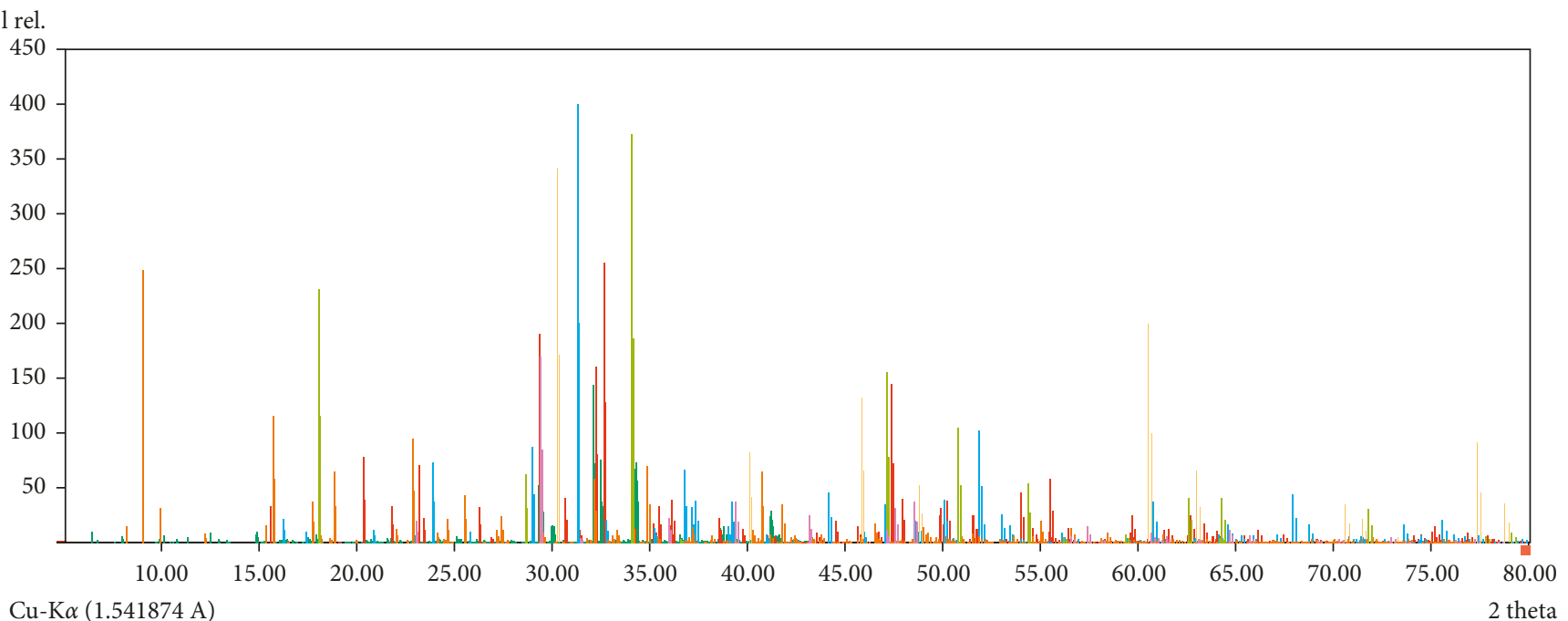

- Experimental pattern: CC

— [96-901-6126] Ca3 O5 Si Alite (19.0\%)

— [96-231-0676] Ca2 O4 Si Ca2 (Si O4) (18.6\%)

— [96-901-0521] Al1.91 Ca2 Fe0.02 Mg0.05 O7 Si1.02 Gehlenite (16.4\%)

— [96-154-4734] O2 Si SiO2 stishovite at $1.99 \mathrm{GPa}(15.9 \%)$

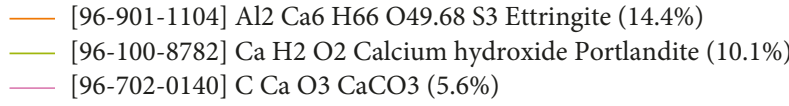
— [96-154-4732] O2 Si SiO2 (stishovite at 1 bar)

Figure 11: X-ray diffractogram of the mix CC at 28 days.

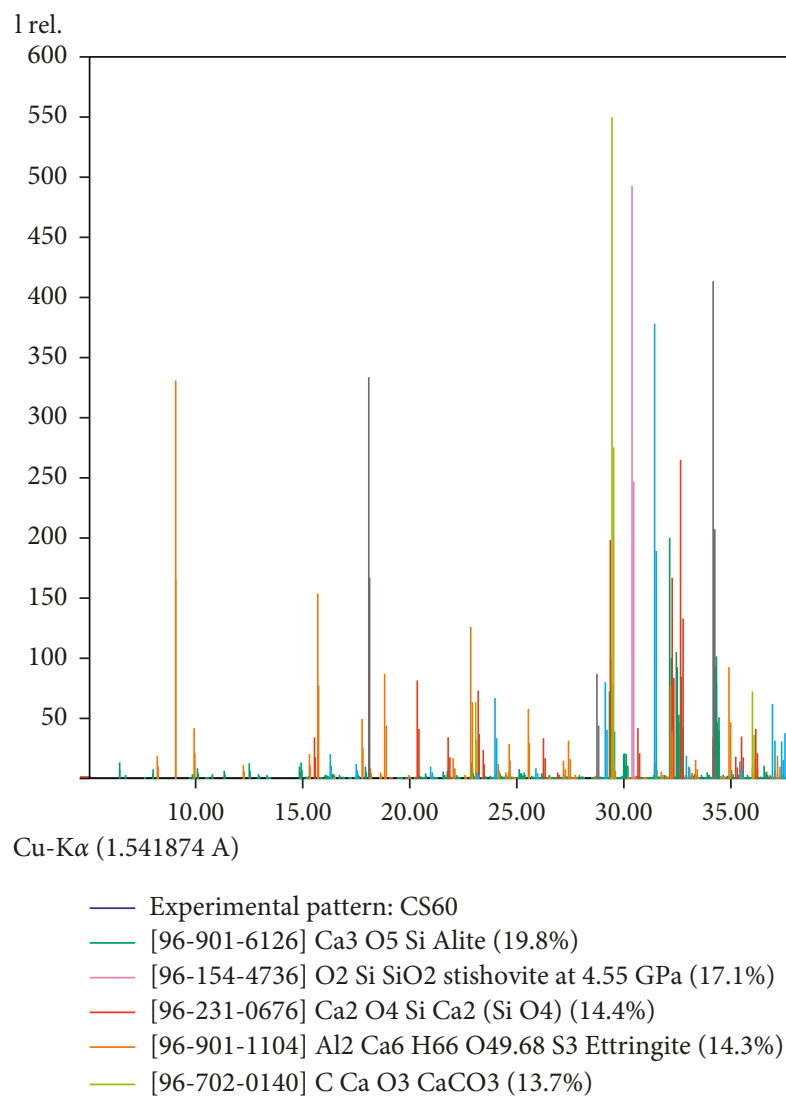

Figure 12: X-ray diffractogram of the mix CS60 at 28 days.

present in the concrete mixes CS60 and CS100 is $13.7 \%$ and $16.9 \%$, respectively. The high amount of $\mathrm{CaCO}_{3}$ compared to the mixes CC and CW2 could possibly indicate hindered crystallization of the portlandite and might have caused reduction in the strength of the concrete mixtures [24]. 


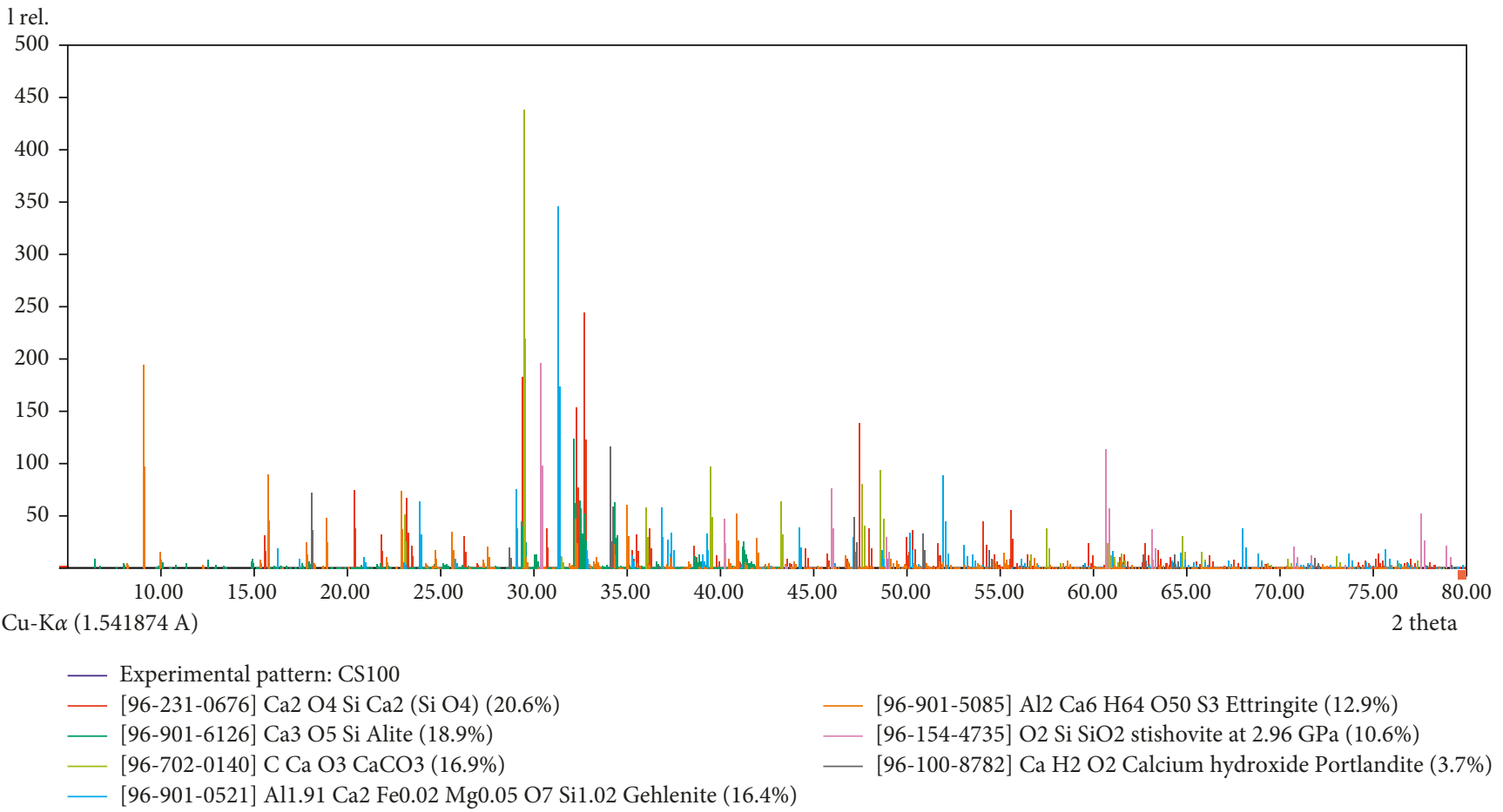

FIGURE 13: X-ray diffractogram of the mix CS100 at 28 days.

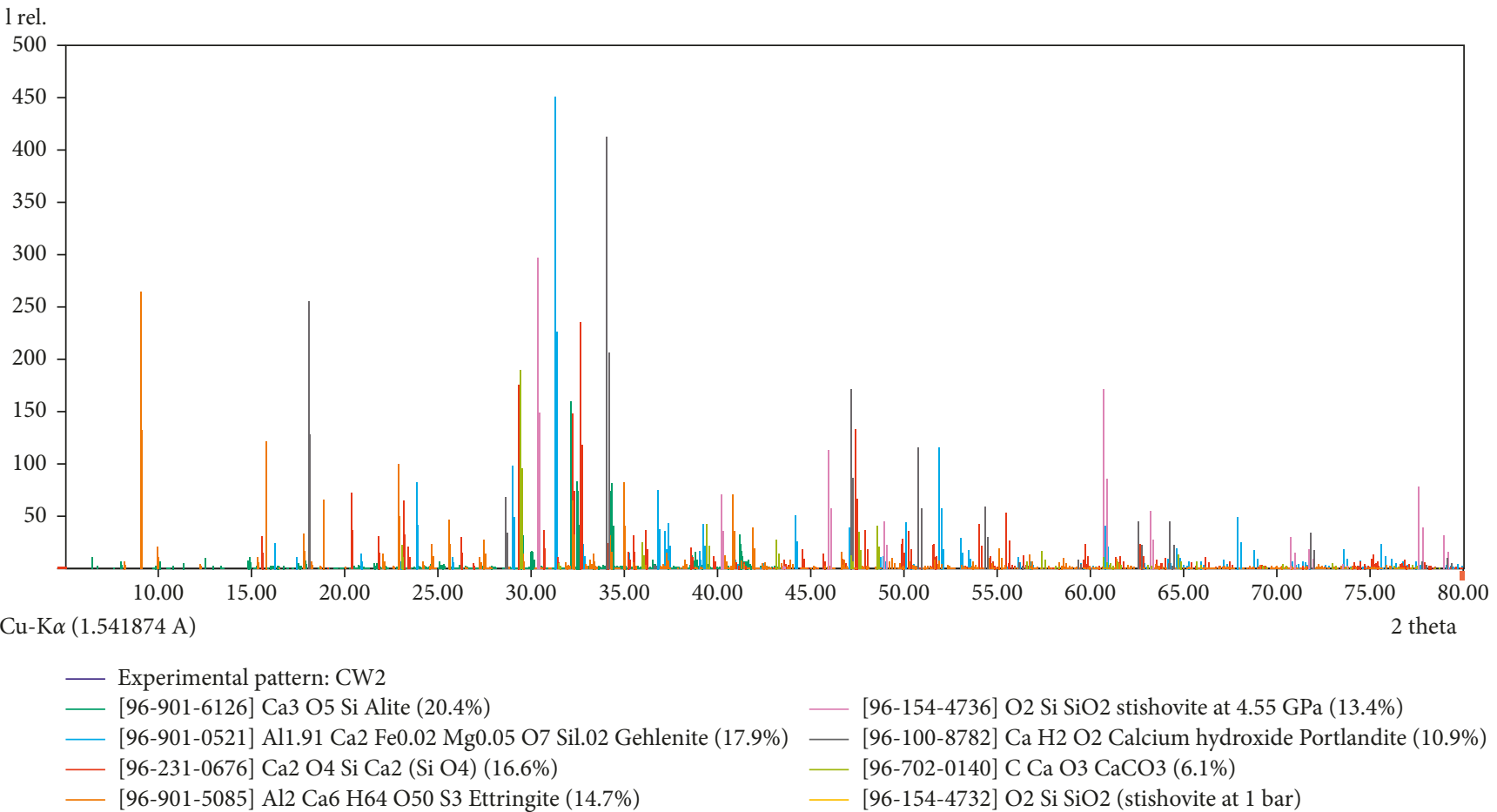

Figure 14: X-ray diffractogram of the mix CW2 at 28 days.

\section{Conclusion}

For the continuing development, the construction of buildings and infrastructure is unavoidable. The environmental impact of construction activities is becoming a bigger and bigger concern with increasing global interest in sustainable development. The use of industrial wastes in concrete is a key driver towards the sustainable construction. The findings of the present experimental work undertaken to ascertain the feasibility of utilizing 
copper slag as a substitute for natural sand infer that copper slag possesses a great potential to be utilized as fine aggregate in concrete.

The following are the outcomes of the present experimental study:

(1) There is a significant drop in water demand when copper slag is used as a substitute for fine aggregate in concrete, which results in the improved workability of concrete.

(2) The density of the copper slag concrete is greater than that of control concrete for the obvious reason that the specific gravity of the natural sand is about three-fourths of that of copper slag.

(3) Partial substitution of sand by copper slag effectively improves compressive strength of concrete up to $60 \%$ substitution level, whereas the strength of concrete at $70 \%$ substitution remains similar to that of control concrete.

(4) The split tensile and flexural strength of concrete also improved up to $60 \%$ copper slag substitution for natural sand. However, these values lowered for a further increase in substitution percentage.

(5) Presence of high $\mathrm{CaCO}_{3}$ in the mixes $\mathrm{CS} 60$ and CS100 could have hindered the crystallization of the portlandite and might have resulted in the reduction of the strength in these mixes.

(6) The strength of the concrete containing copper slag significantly improves when the water content is reduced because of the reduction in free water available in the mix.

(7) Reduction in the w/c ratio enhances the strength due to decline in free water available as long as enough water is available for proper hydration reaction.

(8) It is recommended to use copper slag as fine aggregate in concrete up to $70 \%$ substitution level.

\section{Conflicts of Interest}

The authors declare that they have no conflicts of interest.

\section{References}

[1] P. Onprom, K. Chaimoon, and R. Cheerarot, "Influence of bottom ash replacements as fine aggregate on the property of cellular concrete with various foam contents," Advances in Materials Science and Engineering, vol. 2015, Article ID 381704, 11 pages, 2015.

[2] N. Ghafoori and J. Bucholc, "Investigation of lignite-based bottom ash for structural concrete," Journal of Materials in Civil Engineering, vol. 8, no. 3, pp. 128-137, 1996.

[3] P. Aggarwal, Y. Aggarwal, and S. M. Gupta, "Effect of bottom ash as replacement of fine," Asian Journal of Civil Engineering (Building and Housing), vol. 8, no. 1, pp. 49-62, 2007.

[4] L. B. Andrade, J. C. Rocha, and M. Cheriaf, "Influence of coal bottom ash as fine aggregate on fresh properties of concrete," Construction and Building Materials, vol. 23, no. 2, pp. 609614, 2009.
[5] Y. Bai, F. Darcy, and P. A. M. Basheer, "Strength and drying shrinkage properties of concrete containing furnace bottom ash as fine aggregate," Construction and Building Materials, vol. 19, no. 9, pp. 691-697, 2005.

[6] Z. Zhu, B. Li, and M. Zhou, "The influences of iron ore tailings as fine aggregate on the strength of ultra-high performance concrete," Advances in Materials Science and Engineering, vol. 2015, Article ID 412878, 6 pages, 2015.

[7] B. Tripathi and S. Chaudhary, "Performance based evaluation of ISF slag as a substitute of natural sand in concrete," Journal of Cleaner Production, vol. 112, pp. 672-683, 2016.

[8] R. K. Al-Bawi, I. T. Kadhim, and O. Al-Kerttani, "Strengths and failure characteristics of self-compacting concrete containing recycled waste glass aggregate," Advances in Materials Science and Engineering, vol. 2017, Article ID 6829510, 12 pages, 2017.

[9] K. S. Al-Jabri, M. Hisada, S. K. Al-Oraimi, and A. H. Al-Saidy, "Copper slag as sand replacement for high performance concrete," Cement and Concrete Composites, vol. 31, no. 7, pp. 483-488, 2009.

[10] M. F. M. Zain, M. N. Islam, S. S. Radin, and S. G. Yap, "Cement-based solidification for the safe disposal of blasted copper slag," Cement and Concrete Composites, vol. 26, no. 7, pp. 845-851, 2004.

[11] M. Khanzadi and A. Behnood, "Mechanical properties of high-strength concrete incorporating copper slag as coarse aggregate," Construction and Building Materials, vol. 23, no. 6, pp. 2183-2188, 2009.

[12] K. S. Al-Jabri, M. Hisada, A. H. Al-Saidy, and S. K. Al-Oraimi, "Performance of high strength concrete made with copper slag as a fine aggregate," Construction and Building Materials, vol. 23, no. 6, pp. 2132-2140, 2009.

[13] W. Wu, W. Zhang, and G. Ma, "Optimum content of copper slag as a fine aggregate in high strength concrete," Materials \& Design, vol. 31, no. 6, pp. 2878-2883, 2010.

[14] W. Wu, W. Zhang, and G. Ma, "Mechanical properties of copper slag reinforced concrete under dynamic compression," Construction and Building Materials, vol. 24, no. 6, pp. 910917, 2010.

[15] D. Brindha and S. Nagan, "Durability studies on copper slag admixed concrete," Asian Journal of Civil Engineering (Building and Housing), vol. 12, no. 5, pp. 563-578, 2011.

[16] BIS: 12269-2013, Ordinary Portland Cement 53 Grade-Specification, Bureau of Indian Standards, Delhi, India, 2013.

[17] BIS: 2386 part III-1963, R 2002, Method of Test for Aggregate for Concrete, Part III Specific Gravity, Density, Voids, Absorption and Bulking, Bureau of Indian Standards, Delhi, India, 2002.

[18] BIS: 10262-2009, Indian Concrete Mix Design Guide Lines, Bureau of Indian Standards, Delhi, India, 2009.

[19] BIS: 1199-1959, R 2004, Methods of Sampling and Analysis of Concrete, Bureau of Indian Standards, Delhi, India, 1959.

[20] BIS: 516-1959, R 2004, Method of Tests for Strength of Concrete, Bureau of Indian Standards, Delhi, India, 2004.

[21] BIS: 5816-1999, R 2004, Splitting Tensile Strength of Concrete, Bureau of Indian Standards, Delhi, India, 2004.

[22] K. S. Al-Jabri, A. H. Al-Saidy, and R. Taha, "Effect of copper slag as a fine aggregate on the properties of cement mortars and concrete," Construction and Building Materials, vol. 25, no. 2, pp. 933-938, 2011.

[23] BIS: 456-2000, R 2005, Plain and Reinforced Concrete, Bureau of Indian Standards, Delhi, India, 2000.

[24] R. Gabrovsek, T. Vuk, and V. Kaucic, "Evaluation of the hydration of portland cement containing various carbonates by mean of thermal analysis," Acta Chimica Slovenica, vol. 53, no. 2, pp. 159-165, 2006. 


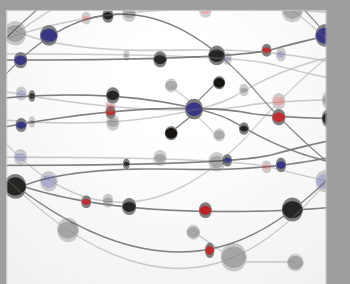

The Scientific World Journal
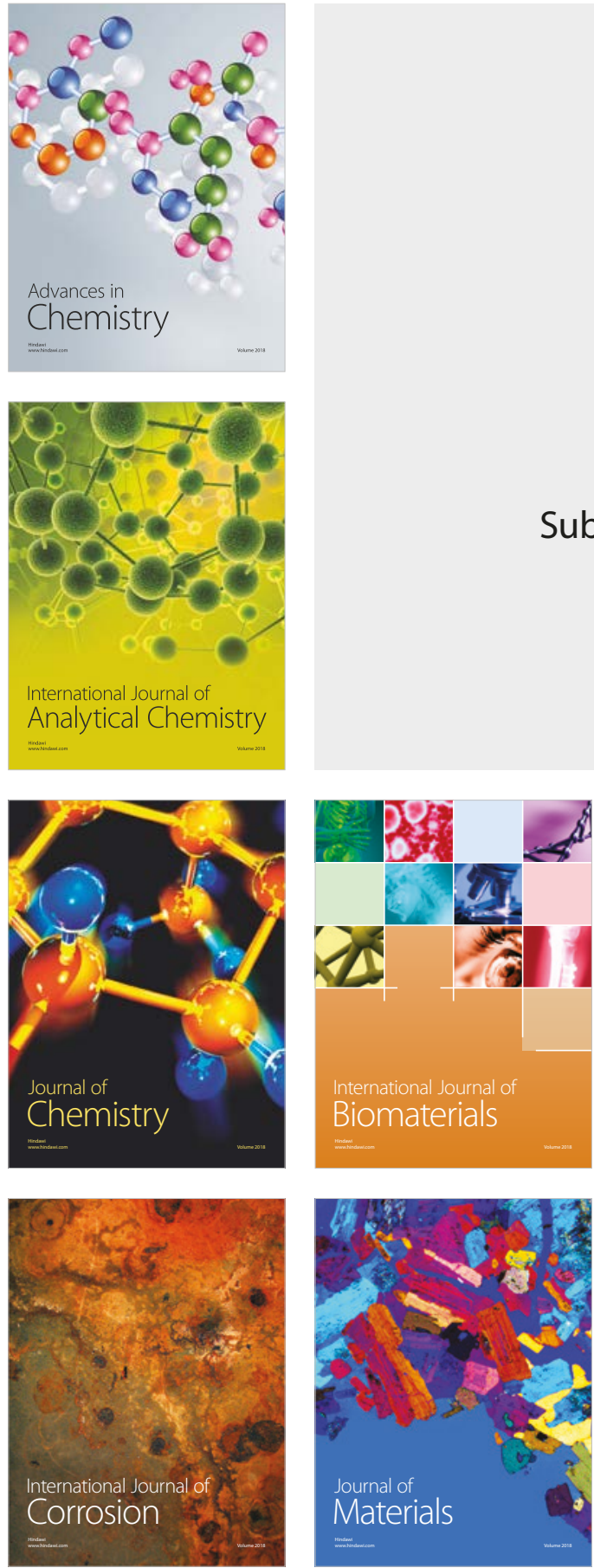

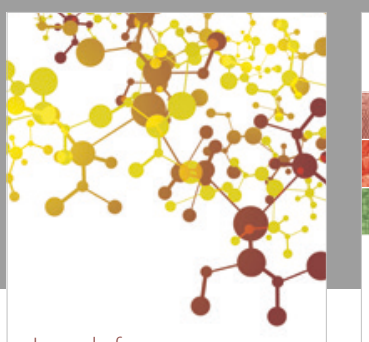

Journal of

Applied Chemistry
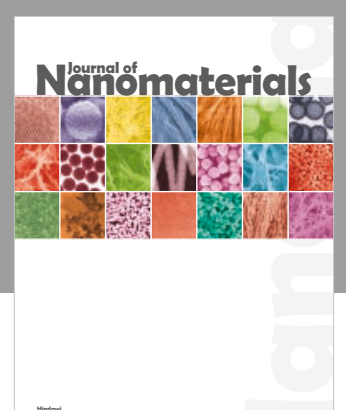

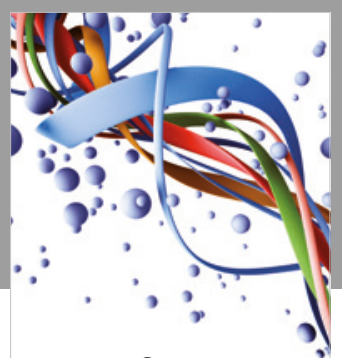

Scientifica

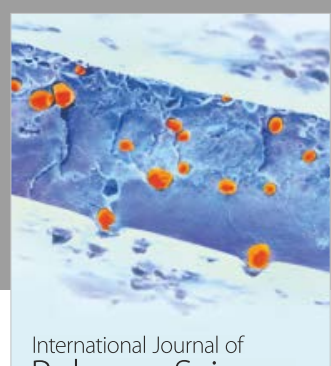

Polymer Science

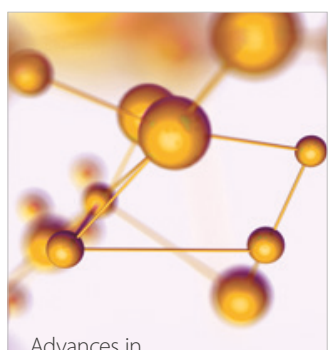

Physical Chemistry
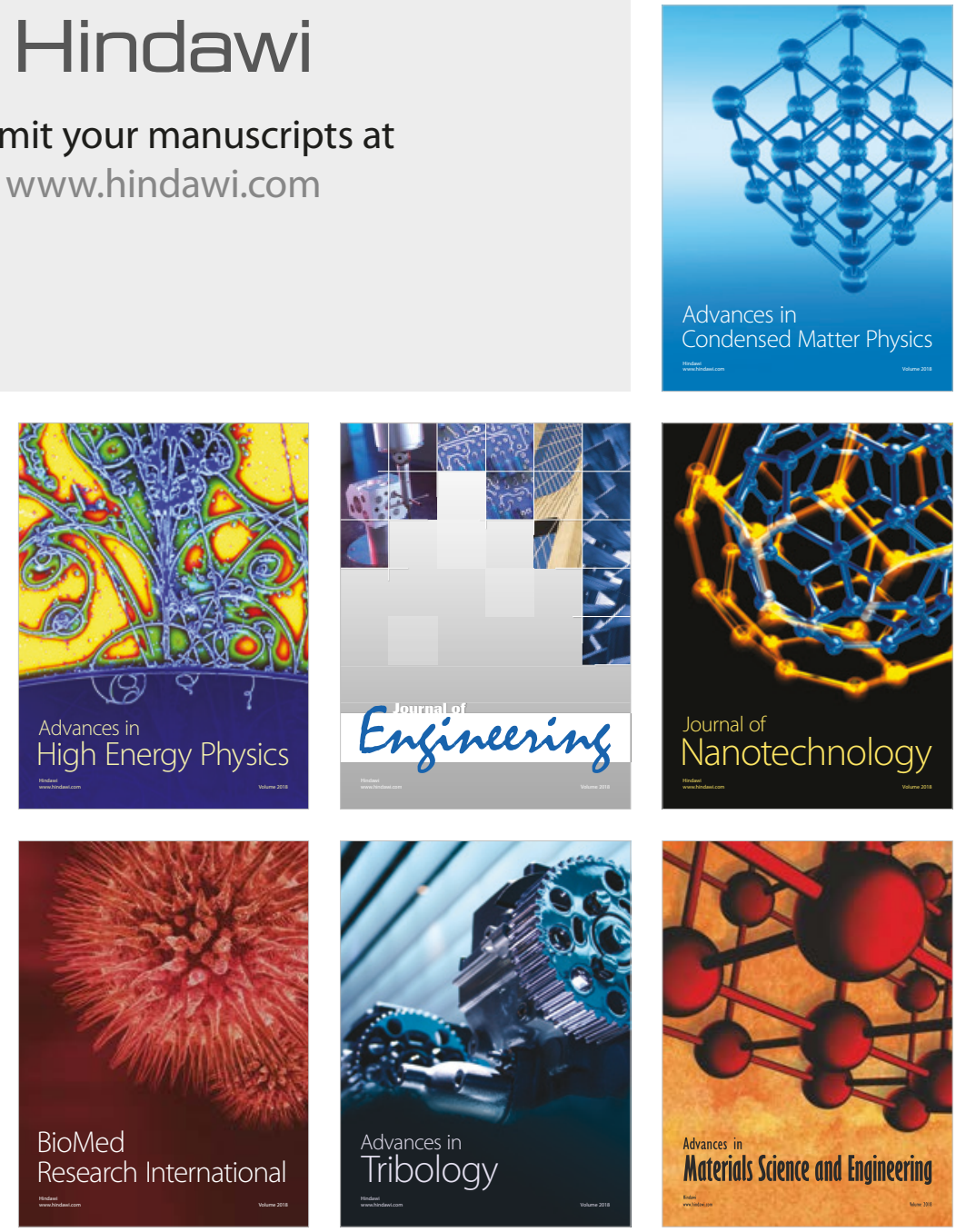